\title{
Publisher Correction: Relaxed selection underlies genome erosion in socially parasitic ant species
}

Lukas Schrader (D), Hailin Pan, Martin Bollazzi (D), Morten Schiøtt (D), Fredrick J. Larabee D , Xupeng Bi, Yuan Deng, Guojie Zhang (D), Jacobus J. Boomsma (1) \& Christian Rabeling (D)

Correction to: Nature Communications https://doi.org/10.1038/s41467-021-23178-w, published online 18 May 2021.

The original version of this Article contained an error in Fig. 1, in which the species names are incorrectly displayed. The correct version of Fig. 1 is:

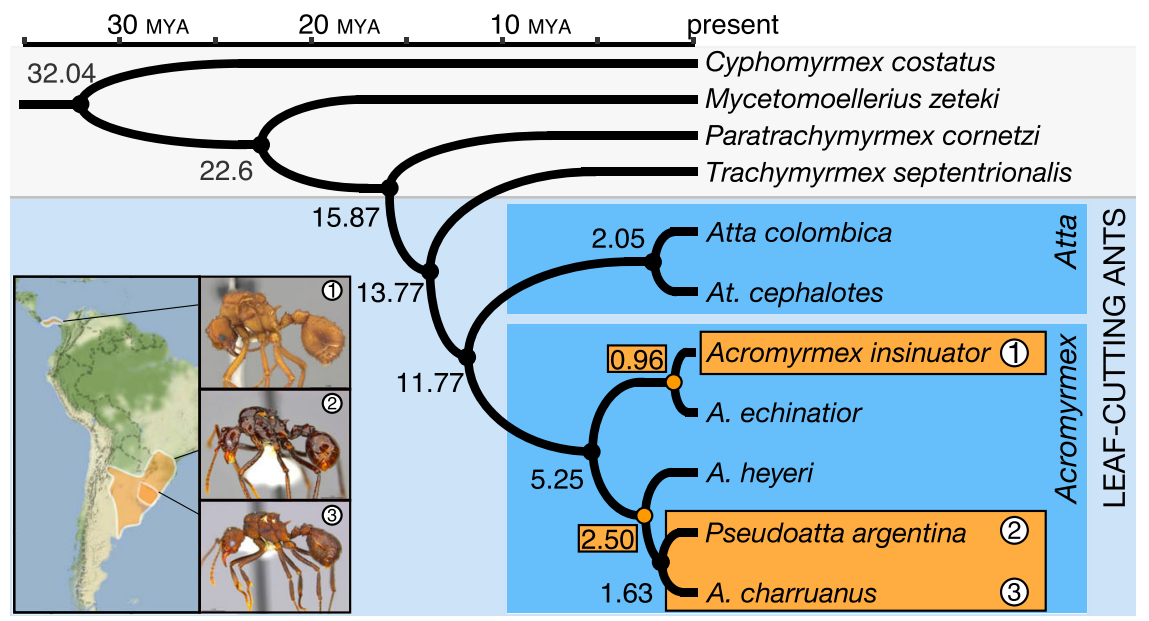

The error has been corrected in both the PDF and HTML versions of the Article.

Published online: 15 June 2021

Open Access This article is licensed under a Creative Commons Attribution 4.0 International License, which permits use, sharing, adaptation, distribution and reproduction in any medium or format, as long as you give appropriate credit to the original author(s) and the source, provide a link to the Creative Commons license,
and indicate if changes were made. The images or other third party material in this article are included in the article's Creative Commons license, unless indicated otherwise in a credit line to the material. If material is not included in the article's Creative Commons license and your intended use is not permitted by statutory regulation or exceeds the permitted use, you will need to obtain permission directly from the copyright holder. To view a copy of this license, visit http://creativecommons.org/licenses/by/4.0/.

(c) The Author(s) 2021 